the Association, and here, as at Porton, he was faced with the problem of creating an organisation from the beginning. The Shirley Institute comprised a large private house situated in its own grounds but bearing no semblance to a scientific institution. He had to undertake the difficult task of installing laboratories and equipment which could deal effectively with the problems arising in this basic industry. Such problems would necessarily cover a wide field, including many branches of science, and would, therefore, entail the initiation and control of researches in subjects other than chemistry. He had not only to help the industry by research on scientific lines, but also had to accomplish the still more delicate task of appealing by the work of the Institute to those who were anxious for immediate practical results and were not always cognisant of the essential need for fundamental research as a foundation for industrial progress. It is a remarkable fact that in two years, that is to say, in approximately the same time as was taken to organise Porton, the Shirley Institute was established as a fully equipped research unit and was formally opened by the Duke of York in 1922. Since then the volume of research work from the Institute has not only made it a model research association, but has also, by reason of the practical application of its work, convinced many who were previously sceptical of the value of fundamental research in relation to the industry.

Despite his many other activities, Crossley found time to devote himself to other public work, and was from 1903 until 1913 secretary of the Chemical Society and from 1913 until 1925 its foreign secretary. In the latter year he was president of the Society, but had to relinquish the office after one year owing to failing health. He was a man, therefore, who gave great and useful service to his country, and received the recognition of his King, his University, and his fellow scientific workers. Had he lived he would have attained to greater honours, for the full power of his work will not be realised until the lapse of time has proved its value. Without question his life was shortened by his devotion to public duty and by the strain imposed on his constitution by the high sense of responsibility he felt in all the work he undertook. The War years imposed a heavy burden, which, although cheerfully borne, nevertheless left its mark on a not too robust constitution, and henever seemed quite the same man afterwards. He was essentially a pioneer, for his great activity of mind led him to seek new problems as soon as he had settled the one in hand to his own satisfaction and had brought it to a stage at which he felt he could safely hand it over to others. He was denied, therefore, the complacent rest which ought to follow the contemplation of smoothly running administrative machinery well and truly constructed.

J. F. T.

\section{F. E. TurpIN}

M. François Eugkine TuRPIN, well known as the inventor of melinite, one of the high explosives used in shell-filling, died on Jan. 24 at Pontoise.
We are indebted to a recent issue of La Nature for the following particulars of his life. After his birth at Rosendael in 1849 his parents moved to Paris, where, on leaving school, he began to study medicine. But he became interested in chemical research, and it was not long before his natural skill in experimental work was publicly recognised by the bestowal upon him by the Paris Academy of Sciences of the Montyon prize for his invention of harmless colouring matters for children's toys, This invention presently involved him in some litigation, but, nothing daunted, he applied himself with energy to the study of explosives. Those were the days of black gunpowder, dynamite, and gun-cotton. The instability of nitrated organic compounds had rendered them unfit for use by the artillery and even unsafe to store in magazines. With the object of overcoming these difficulties Turpin decided to abandon the search for suitable material among aliphatic compounds and turned his attention to those of the aromatic series. After seven years of ceaseless toil he perfected a process for preparing a suitable high explosive from picric acid by the simple device of melting it in an oilbath and running it into moulds. When, shortly afterwards, a suitable detonator had been devised for use with the new explosive, the French Government purchased the new process from him; but the secret appears to have been treacherously revealed to a British firm by an artillery officer, whom Turpin vigorously denounced in a volume entitled "Comment on a vendu la mélinite." For this indiscretion Turpin was prosecuted, and eventually condemned to prison on the charge of having revealed in his book secrets of importance to the national defence. After spending nearly two years in prison he was pardoned in 1893, and in 1901 he was completely restored to favour by being elected to serve as a technical adviser to the artillery. In this capacity he rendered invaluable service to France until after the War, when the State awarded him an annuity.

Prof. Carl Graebe, who died after a long illness on Jan. 19 in his native town, Frankfort, within a few weeks of completing his eighty-sixth year, had for many years occupied with distinction the chair of chemistry at Geneva. Graebe's reputation was made by his brilliant researches on the constitution of aromatic and heterocyclic compounds, particularly on quinones, phthalic acid, alizarin, and acridine. He also succeeded in demonstrating the constitution of anthracene, phenanthrene, fluorene, carbazol, etc., and was a pioneer in the investigation of the relationship between colour and chemical constitution. Having shown that alizarin was derived not from naphthalene but from anthracene, the synthesis of that important dyestuff could not be long delayed, and the solution of this problem in 1868 by Graebe and Liebermann marks an important stage in the development of the dyestuff industry. Graebe was also the author of a work on the history of organic chemistry.

No. 2996, Vox. 1191 